\title{
KONSTRIBUSI ALUMNI PGMI FITK UIN RADEN FATAH DALAM UPAYA MEMBANGUN PENDIDIKAN DI PERBATASAN SUMATERA SELATAN (STUDI MULTISITUS OKU SELATAN DAN EMPAT LAWANG)
}

\author{
Amir Hamzah,M.Pd \\ Prodi PGMI FITK UIN Raden Fatah Palembang \\ Email :Amirhamzah_uin@radenfatah.ac.id
}

\begin{abstract}
Abstrak Sumatera Selatan adalah salah satu provinsi di Indonesia yang terletak di bagian selatan Pulau Sumatera. Provinsi ini beribukota di Palembang. Secara geografis provinsi Sumatera Selatan berbatasan dengan provinsi Jambi di utara, provinsi Kep. Bangka-Belitung di timur, provinsi Lampung di selatan dan Provinsi Bengkulu di barat. Secara perkembangan sumatera selatan mengalami perkembangan pendidikan yang sangat baik bisa kita lihat dari tahun ke tahun sumatera selatan selalu ada event nasional maupun internasional sebagai bentuk kepercayaan masyarakat nasional dan internasional.

Alumni PGMI Fakultas Ilmu Tarbiyah dan Keguruan UIN Raden Fatah adalah sarjana strata 1 yang membidangi Pendidikan Madrasah Ibtidaiyah/ Pendidikan Dasar di daerah Sumatera Selatan tujuan dari penelitian ini adalah, tujuan penelitian ini adalah untuk mengetahui peran alumni PGMI terhadap pembangunan pendidikan di perbatasan Sumatera Selatan, Implementasi alumni PGMI di bidang Madrasah Ibtidaiyah dan kendala yang di alami oleh alumni PGMI di perbatasan Sumatera Selatan dan solusi apa yang bisa di berikan untuk daerah perbatasan sumatera selatan studi multisitus (OKU Selatan dan Empat Lawang)

Penelitian dilakukan dengan pendekatan kualitatif. Pendekatan kualitatif yaitu strategi dan teknik penelitian yang digunakan untuk memahami masyarakat, masalah atau gejala dalam masyarakat dengan mengumpulkan sebanyak mungkin fakta mendalam, data disajikan dalam bentuk verbal bukan bentuk angka, penelitian menggunakan dua tempat yaitu OKU Selatan dan Empat Lawang (Multisitus)

.Konstribusi alumni di perbatasan ialah alumni yang bekerja di kabupaten dalam berbagai sektor mulai dari Pemerintahan, Pendidikan dan Kemasyarakatan, peran alumni di ruanglingkup Madrasah Ibtidaiyah ialah Pengembangan Kurikulum 2013, Pengembangan media pembelajaran, peningkatan ekstrakulikuler di Madrasah Ibtidaiyah dan sekolah dasar, dan pembiasaan belajar qur'an tahfiz jus 30. Kendala yang di hadapi alumni ialah adanya gap antara alumni PGSD dan PGMI di beberapa daerah, sarana prasarana, minim komunikasi, ekonomi orang tua/peran orang tua belum teralu akif dan perkembangan psikologi anak
\end{abstract}

Kata Kunci :Konstribusi, Alumni, Perbatasan

\section{A. Konteks Penelitian}

Sumatera Selatan adalah salah satu provinsi di Indonesia yang terletak di bagian selatan Pulau Sumatera. Provinsi ini beribukota di Palembang. Secara geografis provinsi 
Sumatera Selatan berbatasan dengan provinsi Jambi di utara, provinsi Kep. BangkaBelitung di timur, provinsi Lampung di selatan dan Provinsi Bengkulu di barat.(Wikipedia:sumsel) Secara perkembangan sumatera selatan mengalami perkembangan pendidikan yang sangat baik bisa kita lihat dari tahun ke tahun sumatera selatan selalu ada event nasional maupun internasional sebagai bentuk kepercayaan masyarakat nasional dan internasional.

Dalam sektor pendidikan sumatera selatan terkategori baik untuk level nasional hal itu bisa di lihat dari beberapa prestasi yang di torehkan oleh siswa-siswi yang ada di sumatera selatan yang terakhir siswa sumsel menjadi siswa dengan nilai uin tertinggi seperti yang di beritakan media berbagai prestasi skala internasional yang pernah diraih siswa-siswi SMAN Sumsel, yakni Gold Medal of the Asian Pacific Conference of Young Scientists (APCYS), Palembang - Indonesia 2013, Silver Medal of the Mostratec Science Project Olympiad, Sao Paulo - Brazil, 2013,Silver Medal of the Genius Olympiad, New York - USA, 2013, Gold Medal of International Science Project Olympiad (ISPRO), Jakarta - Indonesia 2014, Silver Medal of the International Environment Sustainability Project Olympiad (INESPO), Den Haag - Netherlands, 2014. (Sumatera dealine:online)

Kepala Dinas Pendidikan Sumsel Widodo menyebutkan capaian prestasi dari penerima PKG tersebut membuktikan semangat dan kualitas pendidikan anak-anak Sumsel sangat diperhitungan di luar Indonesia. "PKG akan terus bergulir demi mencetak generasi Sumsel yang mampu bersaing dan sejajar dengan negara-negara lain," bebernya.Namun tidak semua daerah yang ada di sumsel terkategori beprestasi berdasarkan data yang di peringkat pendidikan tercatat bahwa yang sering berprestasi daerah palembang sajaBerdasarkan data yang didapatkan Sripo dari pihak Disdik Sumsel, sekolah asal Kota Palembang baik SMA maupun SMK mendominasi peraih nilai tertinggi dalam kategori sekolah maupun nilai rata-rata siswa perseorangan. (Yuliani:Tribun)

Dan salah satu program studi yang membidangi pendidikan sekolah dasar/Madrasah Ibtidiyah adalah prodi Pendidikan Guru Madrasah Ibtidaiyah(PGMI), Prodi PGMI merupakan salah satu prodi yang berada dalam naungan Fakultas Ilmu Tarbiyah dan Keguruan UIN Raden Fatah Palembang,(Timp Penyusun Silabus PGMI,2015:3) sebagai prodi yang membidangi bidang SD/MI sudah banyak alumni yang berkonstribusi di sumatera selatan dalam sektor pendidikan dasar dapat di lihat dari laporan alumni PGMI yang keseluruhan sudah bekerja di SD/MI/SD-IT maupun instansi lainya, dan di jelaskan oleh ketua program studi PGMI FITK UIN raden fatah palembang menjelaskan mahasiswa/lulusan program studi kedepan menjadi lulusan yang berkualitas karena sudah di bekali bergabagai keahlian selain terampil mengajar di kelas namun di bekali juga dengan keterampilan lainya seperti keterampilan ICT, Tahfidz Qur'an dan KMD pramuka di harapakan dengan program yang di buat oleh program studi akan membantu meningkatkan pendidikan yang ada di sumatera selatan.(Timp Penyusun Silabus PGMI,2015:3) 


\section{B. Kajian Teori}

\section{Pengertian Alumni}

Kata Alumni sudah tidak asing lagi terdengar ditelinga kita terutama pada lembaga dan lainnya. Alumni merupakan bagian hal penting yang ada pada suatu lembaga pendidikan yang di cetak, hal ini juga sangat menentukan suatu eksistensi dan kualitas dari lembaga pendidikan itu sendiri. Pada lembaga pendidikan yang sering kali mencari tau mengenai keberadaan alumninya adalah perguruan tinggi. Perguruan tinggi ini sangat bergantung pada alumni, karena alumni ini lah ayang akan memberikan umpan balik mengenai perkembangan perguruan tinggi itu sendiri melalui tanggapan masyarakat sosial mengenai eksistensi alumni di tengah-tengah masyarakat. Terlebih lagi pada dunia kerja, oleh karena itu harus di paparkan beberapa hal yang berhubungan dengan alumni.

Almuni adalah suatu produk dari suatu proses pendidikan atau dapat dikatakan produk yang di keluarkan atau dihasilkan dari seutu lembaga pendidikan. Dalam hal ini diaratikan bahwa suatu produk itu diperoleh dari hasil proses pendidikan yaitu keberadan alumni ini diharapkan agar mendapat pekerjaan yang sebanding dengan kompetensi dan kemampuan yang sudah dimilikinya dari perguruan tinggi yang telah meluluskannya.

Alumni ini bisa dikatakan sebagai tolak ukur kesuksesan suatu lembaga pendidikan. Hal ini dapat dilihat dari keberadaan alumni yang seharusnya bisa di jadikan indikator dari suatu keberhasilan lembaga pendidikan itu sendiri dalam menbentuk prosuk lulusan yang memiliki nilai yang berkualiats dan memiliki daya saing yang tinggi. Jika para alumni bisa banyak yang diterima dalam duani kerja dan masyarakat sesuai dengan kompetensi yang telah dipunya, maka perguruan tinggi tersebut jugalah sukses menjadi suatu lembaga pendidikan yang mencetak alumni yang bermutu dan berkuatitas tinggi.

2. Peran guru dalam pembangunan pendiidkan

Daoed Yoesoef mengatakan bahwa guru itu memiliki tiga kewajiban utama yaitu pertama profesional, kedua manusiawii dan ketiga kemasyaarakatan. (Arcaro Jerome $\mathrm{S}$ ,2005:90). Guru haruslah mampu membantu peserta didik untuk mengembangkan daya berpikir atau penalaran sedemikian rupa sehingga mampu untuk turut serta secara kreatif. Tugas kemasyarakatan merupakan keharusan guru sebagai warga negara yang baik, turut dan melaksanakan semua yang sudah digariskan oleh bangsa dan negara lewat UUD 1945 dan GBHN. Ketiga kewajiban guru itu haruslah dilaksanakan secara bersama-sama karena dalam menunaikan kewajiban seorang guru haruslah menjadi model atau contoh bagi peserta didiknya, dan sekaligus menjadi fasilitas untuk pesertadidik bertanya, mengemukanan pendapat dan mengembangkan kreativitas dan ilmu-ilmu pengetahuan.

Ketiga kewajiban inilah jika dilihat dari sudut pandang peserta didik maka guru harus mengamalkan nilai yang mengandung pengetahuan masa lalu, masa sekarang dan masa yang akan datang. Ilmu pengetahuan yang kita kasih untuk peserta didik agar bisa membuat peserata didik itu pada saatnya nannti meraka dapat memilih nilai-nilai hidup 
yang semakin utuh dan harus bisa membuat peserta didik berkomunikasi dengan baik di dalam masyarakat, maka dari itulah peserta didik ini tidak bisa hidup secara individu karena manusia ini merupakan makhluk sosial. Peserta didik aharus tau karena cara manusia berkomunikasi dengan orang lain ini sangat beragam macam bentuknya tidak harus selalu dengan menggunakan bahasa akantetapi bisa juga melalui gerakan, tarian, atau bisa juga memalui suara (lagu-lagu), bisa juga melalui warna dan garis-garis (lukisan-lukisan), melalui bentuk berupa ukiran, atau melalui simbol-simbol dan tanda tanda yang biasanya disebut rumus-rumus.

Sehingga dapat disimpulkan nilai-nilai yang diamalkan oleh guru atau tenaga kependidikan dalam rangka melaksanakan kewajibannya, kewajiban yang harus profesional, kewajiban yang harus manusiawi, dan kewajiban yang harus kemasyarakatan, jika di katakan secarakan bersamaan merupakan pengetahuan, pilihan hidup dan praktek komunikasi. Jadi walaupun ucapannya berbeda namanya, oleh karena dipandang dari sudut guru dan dan sudut siswa, namun yang diberikan itu adalah nilai yang sama, maka pendidikan tenaga kependidikan pada umumnya dan guru pada khususnya sebagai pembinaan prajabatan, bertitik berat sekaligus dan sama beratnya pada tiga hal, yaitu melatih mahasiswa, calon guru atau calon tenaga kependidikan untuk mampu menjadi guru atau tenaga kependidikan yang baik, khususnya dalam hal ini untuk mampu bagi yang bersangkutan untuk melaksanakan tugas profesional.( BachmanEdmund,2005:94)

\section{Peranan guru}

WF Connell mengutarakan bahwa terdapat tujuh peran seorang guru yaitu (1) pendidik (nurturer), (2) model, (3) pengajar dan pembimbing, (4) pelajar (learner), (5) komunikator terhadap masyarakat setempat, (6) pekerja administrasi, serta (7) kesetiaan terhadap lembaga.(Danim Sudarwan, 2000:86) Guru bukan hanya sekedar penyampai pelajaran, bukan pula sebagai penerap metode mengajar, melainkan guru adalah pribadinya, yaitu keseluruhan penampilan serta perwujudan dirinya dalam berinteraksi dengan siswa.

H. W. Bernard, menyatakan bahwa pribadi guru lebih dari apa yang diucapkan dan metode yang digunakannya yang menentukan kadar dan arah pertumbuhan siswa. (Permadi ,2001:86) Beliau juga mengemukakan bahwa banyak penelitian ayng menyatakan adanya akibat langsung pribadi guru terhadap tingkah laku siswa. Dalam keseluruhan pendidikan, guru merupakan faktor utama. Dalam tugasnya sebagai pendidik, guru banyak sekali memegang berbagi jenis peranan yang harus dilaksanakan. Peranan adalah suatu pola tingkah laku tertentu yang merupakan ciri-ciri khas semua petugas dari suatu pekerjaan atau jabatan tertentu. Setiap jabatan atau tugas tertentu akan menuntut pola tingkahlaku tertentu pula dan tingkah laku mana akan merupakan ciri khas dari tugas atau jabatan tadi. Peranan guru adalah setiap pola tingkah laku yang merupakan ciri-ciri jabatan guru yang harus dilakukan guru dalam tugasnya. Peranan ini meliputi berbagai jenis pola tingkah laku, baik dalam kegiatannya di dalam sekolah maupun di luar sekolah. 


\section{Metodologi Penelitian}

Penelitian dilakukan dengan pendekatan kualitatif. Pendekatan kualitatif yaitu strategi dan teknik penelitian yang digunakan untuk memahami masyarakat, masalah atau gejala dalam masyarakat dengan mengumpulkan sebanyak mungkin fakta mendalam, data disajikan dalam bentuk verbal bukan bentuk angka. (Suharsimi Arikunto, 1996:20) Dilihat dari jenisnya, penelitian ini lebih menekankan pada jenis field research (penelitian kancah atau lapangan) dan bersifat kualitatif. Adapun pendekatan kualitatif ini dilakukan sebagai prosedur penelitian yang menghasilkan data diskripsi berupa kata-kata tertulis atau lisan dari orang-orang dan perilaku yang diamati. (Meleong,2000:4)

Penelitian ini menggunakan post positivistic dengan pendekatan kualitatif, jenis studi kasus dengan rancangan multisitus. Data yang dikumpulkan dengan latar alami (natural setting) sebagai sumber data langsung. Penelitian ini diharapkan mampu mendeskifsikan dan menemukan secara menyeluruh dan utuh mengenai implementasi peraturan sekolah dalam meningkatkan kedisiplinan guru dan siswa di di OKU Selatan dan Empat Lawang. Di samping itu, peneliti ini dapat membangun suatu teori secara induktif yang selanjutnya digunakan untuk mendapatkan temuan substantif sesuai dengan fokus penelitian yang selanjutnya diabstraksikan sebagai temuan formal.

Adapun alasan peneliti menggunakan metode kualitatif ini karena peneliti ingin memahami (how to undertand) secara mendalam masalah yang diteliti dan bukan menjelaskan (how to explain) hubungan sebab akibat sebagaimana yang telah dilakukan oleh peneliti kuantitatif. Selanjutnya, sebagaimana sifat metode penelitian kualititatif pada umumnya, jenis studi kasus dilakukan terhadap peristiwa atau gejala yang sedang berlangsung, bukan gejala atau peristiwa yang sudah selesai (ex post focto). (Mudjia ,2013:8) Unit of analysis dari penelitian ini adalah individu-individu dan kelompok yang ada di madrasah. Karena lokasi penelitian ada dua, dengan karakteristik yang memiliki banyak kesamaan yaitu di OKU Selatan dan Empat Lawang, maka peneliti ini menggunakan studi multisitus. Rancangan studi multisitus adalah suatu rancangan penelitian kualitatif yang beberapa situs atau subjek penelitian.

D. Hasil Penelitian

Deskripsi Umum lokasi penelitian

1. OKU Selatan

Kabupaten Ogan Komering Ulu Selatan (OKU Selatan) adalah salah satu kabupaten di Provinsi Sumatera Selatan. Merupakan hasil pemekaran Kabupaten Ogan Komering Ulu yang diresmikan dengan UU No. 37 Tahun 2003 tanggal 18 Desember 2003. Kabupaten ini diresmikan pada 16 Januari 2004 di Muara Dua, ibu kota kabupaten OKU Selatan.

Pemekaran Kabupaten OKU menjadi tiga kabupaten didukung oleh Surat Pernyataan Dukungan Tokoh Masyarakat dan Partai Politik Kabupaten OKU serta disetujui DPRD Kabupaten OKU dengan Surat Keputusan DPRD Kabupaten OKU Nomor 33 Tahun 2000 tanggal 13 Juli 2000 tentang Persetujuan Terhadap Rencana 
Pemekaran Wilayah Kabupaten OKU. Selanjutnya ditindaklanjuti dengan Surat Keputusan Bupati OKU Nomor 125/10.A/AK/I/2001 tentang Pembentukan Tim Penyusunan Rencana Pemekaran Wilayah Kabupaten OKU.

Batas wilayah Kabupaten Ogan Komering Ulu Selatan adalah Utara Kecamatan Ulu Ogan, Kecamatan Pengandonan, dan Kecamatan Lengkiti Kabupaten Ogan Komering Ulu. Selatan Kabupaten Lampung Barat Provinsi Lampung. Barat Kabupaten Bengkulu Selatan Provinsi Bengkulu dan Kecamatan Semendo Darat Ulu Kabupaten Muara Enim. Timur Kecamatan Martapura Kabupaten Ogan Komering Ulu Timur dan Kabupaten Way Kanan Provinsi Lampung. (Wikipedia:OKUS)

\section{Empat Lawang}

Kabupaten Empat Lawang adalah sebuah kabupaten di Provinsi Sumatera Selatan, Indonesia. Ibukota kabupaten ini terletak di Tebing Tinggi. Kabupaten Empat Lawang diresmikan pada 20 April 2007 setelah sebelumnya disetujui oleh DPR dengan disetujuinya Rancangan Undang-Undangnya pada 8 Desember 2006 tentang pembentukan kabupaten Empat Lawang bersama 15 kabupaten/kota baru lainnya. Kabupaten Empat Lawang merupakan pemekaran dari kabupaten Lahat.

Kabupaten Empat Lawang mempunyai letak geografis sebagai berikut Utara Kabupaten Musi Rawas, Selatan Kabupaten Lahat dan Kabupaten Bengkulu Selatan, Barat Kabupaten Kepahiang dan kabupaten Rejang Lebong, Bengkulu. Timur Kabupaten Lahat. (Wikipedia:Empat Lawang)

\section{Peran alumni PGMI terhadap pembangunan pendidikan di perbatasan Sumatera Selatan}

Peran alumni PGMI di daerah Perbatasan Sumatera Selatan, dalam upaya pembanguanan pendidikan di lakukan dari bebagai sektor diantarnya sebagai berikut

\section{Sekolah}

Sekolah adalah lembaga untuk para Siswa pengajaran siswa/murid di bawah pengawasan guru. Sebagian besar negara memiliki sistem pendidikan formal, yang umumnya wajib. Dalam sistem ini, siswa kemajuan melalui serangkaian sekolah. Namanama untuk sekolah-sekolah ini bervariasi menurut negara (dibahas pada bagian Daerah di bawah), tetapi umumnya termasuk sekolah dasar untuk anak-anak muda dan sekolah menengah untuk remaja yang telah menyelesaikan pendidikan dasar. (Org:Sekolah) Sekolah sebagai sentral pendidikan bagi masyarakat di Indonesia dan dalam Islam, Allah akan meninggikan beberapa derajat orang yang berilmu

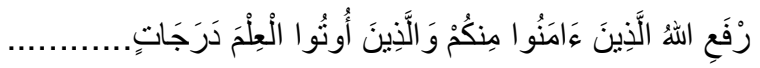

Artinya :"Allah akan meninggikan orang-orang yang beriman di antaramu dan orang-orang yang diberi ilmu pengetahuan."(QS.Al-Mujadalah:11) 
Memberikan perubahan nuansa baru di Sekolah dengan berbagai metode dan media pembelajran, pengajaran yang berbasis pada seluruh aspek kognitif,afektif dan psikomotorik, di sekolah yang ada di Perbatasan sumatera selatan yang alumni lakukan mengajar di sekolah dengan berbagai media pembelajaran, pembiasaan melalui hafalan jus 30, kedisiplinan melalui pramuka, dan kreatifitas membuat kain flanel di Sekolah

2. Lembaga Pemerintahan

KPU adalah salah satu Lembaga pemerintah. Alumni tidak semuanya bekerja di Sekolah ada juga di KPU, sebagai salah satu cara untuk pembangunan daerah melalui KPU. KPU Kabupaten/Kota mempunyai tugas dan kewenangan: (a), memimpin dan melaksanakan seluruh tahap kegiatan Pemilihan Umum, sebagaiman ditentukan dalam perundangundangan yang berlaku; (b) Membentuk, memberi arahan dan mengkoordinasikan organisasi Pelaksanaan Pemilihan Umum di tingkat Provinsi, dan kabupaten/kota, serta panitia Pemilihan Luar Negeri (PPLN); (c) Menyusun dan menetapkan tata cara serta tata laksana Pemilihan Umum sebagai penjabaran teknis peraturan perundaang-undangan; (d) Merencanakan, memimpin, dan menyelenggarakan pengadaan dan pendistribusian logistik pelaksanaan Pemilihan Umum; (e) Berfungsi mengumpulkan, mensistematisasi, mengolah dan mempublikasikan bahan serta data hasil Pemilihan Umum. (Yuliana, 2017:3)

\section{Pembelajaran non-Formal}

Kursus adalah lembaga pelatihan yang termasuk ke dalam jenis pendidikan non formal. Kursus merupakan suatu kegiatan belajar-mengajar seperti halnya sekolah. Perbedaannya adalah bahwa kursus biasanya diselenggarakan dalam waktu pendek dan hanya untuk mempelajari satu keterampilan tertentu, Peserta Kursus yang telah mengikuti kursus dengan baik dapat memperoleh sertifikat atau surat keterangan. Untuk keterampilan tertentu seperti, kursus ahli kecantikan atau penata rambut diwajibkan menempuh ujian negara. Ujian negara ini dimaksudkan untuk mengawasi mutu kursus yang bersangkutan, sehingga pelajaran yang diberikan memenuhi syarat dan peserta memiliki keterampilan dalam bidangnya.

\section{Karang taruna}

Karang Taruna adalah organisasi kepemudaan di Indonesia. Karang Taruna merupakan wadah pengembangan generasi muda nonpartisan, yang tumbuh atas dasar kesadaran dan rasa tanggung jawab sosial dari, oleh dan untuk masyarakat khususnya generasi muda di wilayah Desa / Kelurahan atau komunitas sosial sederajat, yang terutama bergerak dibidang kesejahteraan sosial. Sebagai organisasi sosial kepemudaan Karang Taruna merupakan wadah pembinaan dan pengembangan serta pemberdayaan dalam upaya mengembangkan kegiatan ekonomis produktif dengan pendayagunaan semua potensi yang tersedia dilingkungan baik sumber daya manusia maupun sumber daya alam yang telah ada. Sebagai organisasi kepemudaan, Karang Taruna berpedoman pada Pedoman Dasar dan Pedoman Rumah Tangga di mana telah pula diatur tentang 
struktur penggurus dan masa jabatan dimasing-masing wilayah mulai dari Desa / Kelurahan sampai pada tingkat Nasional. Semua ini wujud dari pada regenerasi organisasi demi kelanjutan organisasi serta pembinaan anggota Karang Taruna baik dimasa sekarang maupun masa yang akan datang.

\section{TPA (Taman belajar Al-Qur'an}

Taman Pendidikan Al Qur'an (disingkat (TPA/TPQ)) adalah lembaga atau kelompok masyarakat yang menyelenggarakan pendidikan nonformal jenis keagamaan Islam yang bertujuan untuk memberikan pengajaran membaca Al Qur'an sejak usia dini, serta memahami dasar-dasar dinul Islam pada anak usia taman kanak-kanak, sekolah dasardan atau madrasah ibtidaiyah (SD/MI) atau bahkan yang lebih tinggi. TPA/TPQ setara dengan RA dan taman kanakkanak (TK), di mana kurikulumnya ditekankan pada pemberian dasar-dasar membaca Al Qur'an serta membantu pertumbuhan dan perkembangan rohani anak agar memiliki kesiapan dalam memasuki pendidikan lebih lanjut. Hal itu juga yang di lakukan oleh alumni PGMI mengembangkan pembelajaran di daerah melalui kegiatan TPQ

\section{B. Implementasi Alumni PGMI di bidang Madrasah Ibtidaiyah}

Pendidikan di Indonesia pada hakekatnya adalah secara umum adalah yang termaktub dalam pembukaan UUD 1945 alenia ke-4 yaitu untuk "mencerdaskan kehidupan bangsa" sehingga martabat negara akan meningkat di mata dunia. Untuk itu diperlukan sebuah sistem yang dalam penanganannya yang pada intinya menjadikan masyarakat Indonesia menjadi sejahtera dalam kehidupannya baik masyarakat kaya dan dan masyarakat yang kurang beruntung.

Sebagaimana tujuan dari prodi PGMI adalah, Mempersiapkan sarjana pendidikan guru madrasah ibtidaiyah yang berkompeten, unggul, dan berdaya saing tinggi. Alumni PGMI yang berada di Perbatasan sumatera Selatan apakah sudah mengimpelemntasikan ilmu yang di dapat selama berkuliah di prodi PGMI FITK UIN Raden Fatah. Relevansinya dengan perkembangan pendidikan di Madrasah Ibtidaiyah sebagimana misi program studi pendidikan guru madrasah ibtidaiyah menyelenggarakan pendidikan bidang madrasah ibtidaiyah/sekolah dasar berbasis pada profesionalitas yang memiliki keunggulan. Berdasarkan keharusan di atas apakah kondisi di lapangan sama dengan yang di cita-citakan bangsa. Dari pemaparan data di atas ada beberapa inovasi Alumni PGMI yang di lakukan di daerah perbatasan sumatera selatan di antaranya :

\section{Pemahaman Kurikulum 2013}

Pemahaman kurikulum merupakan kemampuan guru untuk menerangkan, mengklasifikasikan, mengembangkan dan mengimplementasikan konsep-konsep kurikulum yang disusun dan dilaksanakan oleh masing-masing satuan pendidikan untuk mewujudkan tujuan pendidikan nasional. (Andi,2015:10), Berdasarkan data di lapangan alumni PGMI memahami kurikulum 2013 karena sdi Universitas di pelajari pada waktu 
kuliah dan di setiap magang sekolah pelaksanaan di sekolah melaksanakan kurikulum 2013

\section{Pengembangan media Pembelajaran}

Kata "media" berasal dari bahasa Latin "medium" yang berarti "perantara" atau "pengantar". Lebih lanjut, media merupakan sarana penyalur pesan atau informasi belajar yang hendak disampaikan oleh sumber pesan kepada sasaran atau penerima pesan tersebut. Penggunaan media pengajaran dapat membantu pencapaian keberhasilan belajar. Ditegaskan oleh Danim bahwa hasil penelitian telah banyak membuktikan efektivitas penggunaan alat bantu atau media dalam proses belajar-mengajar di kelas, terutama dalam hal peningkatan prestasi siswa. Terbatasnya media yang dipergunakan dalam kelas diduga merupakan salah satu penyebab lemahnya mutu belajar siswa (Nunu Mahnun, 2012:2). Dalam hal ini alumni PGMI mengembangkan media pembelajaran salah satunya melalui kain flanel yang di lakukan oleh saudara $\mathrm{F}$

3. Kegiatan Ekstrakuler

\section{Pasal 1}

Dalam Peraturan Menteri ini yang dimaksud dengan:

1. Kegiatan Ekstrakurikuler adalah kegiatan kurikuler yang dilakukan oleh peserta didik di luar jam belajar kegiatan intrakurikuler dan kegiatan kokurikuler, di bawah bimbingan dan pengawasan satuan pendidikan.

\section{Kendala Alumni di daerah perbatasan Sumatera Selatan}

Beberapa kendalah yang di alami oleh alumni di daerah perbatasan dan solusi yang bisa di berikan

1. Adanya perbedaan perlakuan terhadap alumni PGMI dan PGSD dalam pendaftaran CPNS

Lulusan PGMI boleh mengajar di SD dan apakah lulusan PGSD boleh mengajar di Madrasah Ibtidaiyah. Pada awalnya dalam pikiran saya tidak ada perbedaan antara jurusan PGMI dan PGSD lulusannya sama-sama akan menjadi guru kelas ditingkat SD sederajat. Namun keyakinan saya mulai goyah saat mengobrol dengan salah seorang guru. Beliau mengingatkan bahwa mengambil jurusan sekarang harus linier atau serumpun ilmu, jika tidak akan susah saat mencari pekerjaan nanti. Salah satu kasus yakni masalah PGSD dan PGMI tadi, kedua jurusan tadi sama dengan SPG dan PGA di zaman dulu yang mencetak guru umum yang di bawah naungan Diknas serta PGA yang mencetak guru agama di bawah naungan Depag.

\section{Sarana prasarana}

Sarana dan prasarana pembelajaran merupakan faktor yang tidak dapat di abaikan keberadaan dan peranannya sebagai factor pendukung terhadap keberhasilan kegiatan pembelajaran di sekolah. Dukungan sarana dan prasarana pembelajaran sangatlah nyata 
terutama terhadap tumbuhnya motivasi belajar para siswa dan pada gilirannya kelak akan memberikan efek yang berarti terhadap hasil belajar mereka. Dengan kata lain bahwa sarana dan prasarana pembelajaran memberikan pengaruh terhadap motivasi belajar para siswa ( Saniatul Nisaul Jannah dan Uep Tatang, 2018,2)

\section{Komunikasi}

Seperti yang diketahui bahwa kegiatan komunikasi adalah salah satu unsur dari fungsi manajemen yang sangat penting yang tidak bisa dipisahkan di samping fungsifungsi lainnya seperti perencanaan,pengawasan,pengorganisasiand an lain-lainnya. Sudah barang tentu komunikasi yang diharapkan adalah komunikasi dua arah karena untuk mengetahui apakah pesan yang disampaikan benar-benar dapat mencapai sasarannya. (Mardani,2014:4)

\section{Peran orang tua}

Orang tua adalah guru yang paling utama dan yang pertama memberikan pendidikan kepada anaknya dan bertanggung jawab penuh terhadap proses pertumbuhannya. Seorang anak sangatlah membutuhkan bimbingan dari orang tuanya sehingga kelak bisa menjalani kehidupannya sendiri, dalam hal ini terutama bagi remaja putri yang kelak juga akan menjadi ibu yang akan membimbing anaknya kelak, begitu pentingnya peran orang tua yang menjadi sentral pendidikan baik moral maupun emosi anaknya, menjadikan karekter dan kepribadian orang tua juga berpengaruh dalam mendidik anaknya (Aryati, 2013:87)

\section{Mental peserta didik}

Psikologi pendidikan merupakan sebuah proses pembelajaran yang terjadi dan dilakukan antara pendidik dengan peserta didik. Artinya Bagaimana pendidik dalam proses pembelajaran dapat memahami dan mengetahui secara baik terhadap sifat dan prilaku dari peserta didik. Sehingga apa yang di sempaikan oleh seorang pendidik kepada peserta didik akan diterima dan dapat dipahami secara baik. Namun seorang pendidik, akan menemukan sebuah kegagalan, jika tidak mampu untuk memahami sifat dan perilaku peserta didik secara baik. (Abu Bakar, 2011:3)

\section{E. Kesimpulan}

Kontriusi Alumni PGMI FITK UIN Raden Fatah Palembang dalam upaya pembangunan pendidikan di perbatasan sumatera selatan studi multisitus (OKU Selatan berbatasan dengan Lampung dan Empat Lawang berbatasan dengan Bengkulu). Konstribusi alumni di perbatasan ialah alumni yang bekerja di kabupaten dalam berbagai sektor mulai dari Pemerintahan, Pendidikan dan Kemasyarakatan, peran alumni di ruanglingkup Madrasah Ibtidaiyah ialah Pengembangan Kurikulum 2013, Pengembangan media pembelajaran, peningkatan ekstrakulikuler di Madrasah Ibtidaiyah dan sekolah dasar, dan pembiasaan belajar qur'an tahfiz jus 30. Kendala yang di hadapi alumni ialah adanya gap antara alumni PGSD dan PGMI di beberapa daerah, sarana 
prasarana, minim komunikasi, ekonomi orang tua/peran orang tua belum teralu akif dan perkembangan psikologi anak

\section{F. Saran}

1. Sekolah Dasar/Madrasah Ibtidaiyah

Lebih banyak pemanfaatan alumni PGMI di MI dan Sekolah Dasar

\section{Orang tua}

Selalu awasi anak ketika di rumah, berikan perhatian dan kasih sayang pada anak, selalu menjaga lingkungan keluarga yang sehat baik sehat secara fisik dan psikologis dan perhatikan teman-teman anak bermaian jangan sampai salah pergaulan.

3. Instansi terkait

Terus bekerjasama dengan pihak sekolah dan dewan guru agar tericpta siswa-siswi yang baik

\section{Peneliti selanjutnya}

Memperdalam penelitian peran alumni di daerah perbatasan dengan harapan memberikan solusi terbaik bagi pemerintah

Daftar Pustaka

Abu Bakar, Perkembangan Psikologi Anak Dalam Pendidikan Islam Jurnal Sosial Budaya, Vol. 8 No. 02 Juli-Desember 2011

Admin Sumatera deadkine dalam https://sumateradeadline.co.id/21/03/2018/pendidikan/raih-berbagai-prestasi-profilsman-sumsel-dimuat-dalam-buku-profil-sma, di akses pada 17 Juni 2018

Arcaro Jerome S , PendidikanBerbasisMutu. Yogyakarta : Pustaka Pelajar, 2005

Arikunto, Suharsimi, Prosedur Penelitian Suatu Pendekatan Praktek, Jakarta: Rineka Cipta, 1996

Arjayati Rahim, Peranan Orang Tua Terhadap Pendidikan Karakter Remaja Putri Menurut Islam Jurnal Al-Ulum Volume. 13 Nomor 1, Juni 2013 Hal 87-102

BachmanEdmund, MetodeBelajarBerfikirKritisdanInovatif. Jakarta : Prestasi Pustaka, 2005

Danim Sudarwan, Inovasi Pendidikan dalam Upaya Peningkatan Profesionalisme Tenaga Kependidikan, Bandung : Pustaka Setia, 2000

https://id.wikipedia.org/wiki/Sumatera_Selatan di akses pada 14 Juli 2018

Kabupaten Empat Lawang," Wikipedia bahasa Indonesia, ensiklopedia bebas, September10,2018https://id.wikipedia.org/w/index.php?title=Kabupaten_Empat_Lawan g\&oldid=14175787.

Kabupaten Ogan Komering Ulu Selatan," Wikipedia bahasa Indonesia, ensiklopediabebas,September11,2018,https://id.wikipedia.org/w/index.php?title=Kabup aten_Ogan_Komering_Ulu_Selatan\&oldid=14177612.

Mardani Eka Ningrum, Peranan Komunikasi Internal Di Lingkungan Kerja, INDEPT, Vol. 3, No.1, Februari 2013,

Moleong, Lexy J. Metodologi Penelitian Kualitatif, Bandung: PT. Remaja Rosdakarya, 2000 
Mudjia Rahardjo, Mengenal Lebih Jauh Tentang Studi Kasus, Materi S3 MPI Malang, 2013

Nunu Mahnun, Media Pembelajaran Kajian terhadap Langkah-langkah Pemilihan Media dan Implementasinya dalam Pembelajaran), : Jurnal Pemikiran Islam; Vol. 37, No. 1 Januari-Juni

Permadi Dadi, Manajemen Berbasis Sekolah dan Kepemimpinan Mandiri Kepala Sekolah. Bandung : Sarana Panca Karya Nusa, 2001

Saniatul Nisaul Jannah dan Uep Tatang, Sarana Dan Prasarana Pembelajaran Sebagai Faktor Determinan Terhadap Motivasi Belajar Siswa(Jurnal Pendidikan Manajemen Perkantoran Vol.1_No.2_hal. 63-70_Januari 2018

Tim Penyusun dan pengembang silabus PGMI, Silabus Program Studi Pendidikan Guru Madrasah Ibtidaiyah (Palembang :Rafa Press 2015

Yuliana dan Lukman, Peran Komisi Pemilihan Umum (KPU) Kabupaten Takalar Dalam Penyelenggaraan Sistem Pemilihan Umum, Jurnal Konstitusi, Volume 14, Nomor 3, September 2017.

Yuliani, Tribun dalam http://palembang.tribunnews.com/2018/05/02/palembangdominasi-peraih-nilai-un-tertinggi-di-sumatera-selatan 